\title{
ROLE OF CEREBROSPINAL FLUID IL-8 AS A MARKER FOR DIFFERENTIATION BETWEEN ACUTE BACTERIAL AND ASEPTIC MENINGITIS \\ By
}

AMAL TOHAMY ABDELMOEZ ${ }^{1}$, DOAA ZAKARIA ZAKY ${ }^{1}$

AND AMANY M. MAHER ${ }^{2}$

Department of Tropical Medicine, Faculty of Medicine ${ }^{1}$, and Medical Research Center, Molecular Biology Unit ${ }^{2}$, Ain Shams University ${ }^{1,2}$, Cairo11566, Egypt

\begin{abstract}
No doubt, the distinguishing between bacterial and aseptic meningitis in the emergency department could help to limit unnecessary antibiotic use and hospital admissions.

This study evaluated the role of cerebrospinal fluid IL-8 in differentiating acute bacterial meningitis (ABM) from aseptic meningitis (AM). A total of 80 hospitalized patients with clinical presentations of suspected acute meningitis were subjected to estimation of IL-8 CSF concentrations.

The results showed that CSF IL-8 levels were higher in acute bacterial meningitis than in aseptic ones $(\mathrm{p}<0.05)$. The best cut-off value of CSF IL8 for early diagnosis of bacterial meningitis was $3.6 \mathrm{ng} / \mathrm{ml}$ with a sensitivity of $82.5 \%$ and a specificity of $85.0 \%$.
\end{abstract}

Key words: Egypt, Acute Bacterial, Aseptic Meningitis, Marker, Cerebrospinal Fluid Il-8

\section{Introduction}

Meningitis is inflammation of the protective membranes covering the brain and spinal cord, known collectively as the meninges. The inflammation may be caused by infection with viruses, bacteria, or other microorganisms, and less commonly by certain drugs (Ginsberg, 2004). Acute Bacterial meningitis is endemic in Egypt and sporadic cases occurring all over the year (Abdel Ghani et al, 2002).

The delay in the diagnosis and the consequent delay in initiation of treatment can cause death in about $10 \%$ of cases with advanced disease and severe neurological sequel as many as $80 \%$ of survivors (Van den Bos et al, 2005).It is important to distinguish bacterial meningitis from aseptic meningitis during the acute phase of the disease, as this could help to avoid complications and to limit unnecessary antibiotic use and hospital admissions (Tunkel et al, 2004). Clinical features of bacterial meningitis are nonspe- cific. Therefore, the discrimination of cases of bacterial meningitis from other causes by clinical feature alone is often impossible (Thwaites et al, 2005).

At the time being there was no clinical or laboratory method which can solely prove or disprove the diagnosis of acute bacterial or viral meningitis instantly and accurately. Interleukin 8 (IL-8) is a chemokine produced by macrophages and other cell types such as epithelial cells. It is also synthesized by endothelial cells, which store IL-8 in their storage vesicles, the Weibel-Palade bodies (Wolff et al, 1998).

The levels of the inflammatory cytokines, especially of IL-6 and IL-8 in the CSF of patients with bacterial meningitis (BM) were high up to 48 hours after initiation of treatment (Ruskoni et al, 1991) and a staging decline but not to normal limits (Tsangaropoulou-Stinga et al, 2003). These findings along with the observation that levels of the same cytokines in the serum are much lower, led 
to the concept that the production of these cytokines is local as a result of an inflammatory process triggered by bacterial cell wall and membrane elements (Waage et al, 1989).

Masoud et al. (2013) stated that diagnostic procedures to predict the prognosis of acute meningitis are of paramount importance in order to choose the appropriate level of further surveillance. They concluded that the IgG-index was the only independent predictor for unfavourable outcome (GOS $<5)$ in patients especially with aseptic infection. The best cut off value of IgG index for early prediction of unfavorable outcome (GOS < 5) in bacterial meningitis group was $>$ or $=$ 6.75 with AUC of 0.922 and $95 \%$ CI of $0.769-1.07$ and sensitivity of $75 \%$ and specificity of $93.7 \%$. While, in aseptic meningitis infection was $>$ or $=7.9$ with AUC of 1 and $95 \%$ CI of $1.00-1.00$ and sensitivity of $100 \%$ and specificity of $100 \%$.

The aim of the present work was to evaluate of the diagnostic role of CSF IL8 in the differential diagnosis of acute meningitis (bacterial versus aseptic meningitis).

\section{Patients, Materials and Methods}

A total of 80 patients presented for the first time to Embaba Fever Hospital with clinical picture and CSF analysis suggestive of acute meningitis during the period from November 2012 to march 2013 were enrolled in this cross sectional study. They were divided into 2equal groups, based on CSF examination: acute bacterial and acute aseptic meningitis.

The patients with clinical and laboratory manifestations suggestive of tuberculous or cryptococcal meningitis, cerebro-vascular disease, brain tumours or febrile convulsion were excluded; also those patients who received antibiotic treatment more than 2 days were also excluded. Also, examination of urine by Nucleopore technique (AboMadyan et al, 2004) and stool by thicksmear technique (Katz et al, 1972) were carried out for endemic parasites The study aim were explained to patients who met the pre- designed inclusion criteria and they were asked to sign a written informed consent form, and approvals of concerned authorities were obtained.

All patients were subjected to full medical history, thorough clinical examination and laboratory examination for CBC, ESR, CRP, random blood glucose and cerebrospinal (CSF) analysis on the first spinal tap including with assessment of: physical examination, protein and glucose and cell count including total and the differential leukocytic count, in addition to urine and stool analysis to rule out other parasitic infections. On the other hand, the Gram's stain done in all the patients.

The meningitis was defined as acute bacterial according to CSF laboratory findings increased protein $>100 \mathrm{mg} / \mathrm{dl}$, decreased glucose $<40 \mathrm{mg} / \mathrm{dl}$, and leukocyte count 100 $5000 / \mathrm{mm} 3$ with polymorph nuclear leukocyte domination $>80 \%$ ), identification of the bacterial agents in Gram staining, and/or positive bacterial culture (Razonable, 2011). Also, CSF/serum glucose ratio $\leq 0.4$ is indicative of bacterial meningitis (Straus et al, 2006). On the other hand viral meningitis was defined so, if the viral culture, serological testing, pleocytosis, or reverse transcriptase polymerase chain reactions were positive and the bacterial culture was negative (Dubos et al, 2008).

The CSF IL8 was measured for all patients using the AviBion Human IL8 ELISA (Enzyme-Linked Immunosorbent Assay) Kits, which employs an antibody specific for human IL8.

The collected data were coded, tabulated, and statistically analysed using IBM Statistical package for Social Science (SPSS) statistics (V. 20.0, IBM Corp., USA, 2011). Data was presented and suitable analysis was done according to the type of data obtained for each parameter. Receiver operating characteristic curve (ROC) was computed, and the area under the ROC curve (AUROC) was used to evaluate the ability of IL-8 to discriminate bacterial meningitis from asep- 
tic meningitis. Optimum cut-off was defined as the value that maximized the AUROC.

\section{Results}

The demographical characteristics, the results for routine CSF analysis and IL-8 assay results are shown in Table 1. CSF IL-8 concentrations were higher in the bacterial meningitis group with a significant difference when compared to the aseptic meningitis group ( $<<0.05)$.

The IL-8 appeared as an excellent marker for differentiating ABM from aseptic meningitis with cut off value of CSF IL8 for early diagnosis of bacterial meningitis equal to
$3.6 \mathrm{ng} / \mathrm{ml}$ with a sensitivity of $82.5 \%$, a specificity of $85.0 \%$, a negative predictive value of $84.6 \%$, a positive predictive value of $82.9 \%$ and a diagnostic efficacy of $83.8 \%$ (Fig. 1).

In both groups with patient characteristics, there was significant correlation between CSF IL8 and each of ESR \& CSF cells in ABM group. In the aseptic group SCF IL8 was correlated significantly with CSF glucose, otherwise there was no statistical significant correlation found regarding the other parameters (Tab. 2).

Table 1: demographical characteristic, CSF findings and IL 8 concentration in both groups

\begin{tabular}{|l|l|l|l|l|}
\hline Parameter & Acute bacterial meningitis $(\mathrm{n}=40)$ & Aseptic meningitis $(\mathrm{n}=40)$ & $\mathrm{p}$-value & Sig. \\
\hline Age (years) & $35.18 \pm 17.62$ & $35.18 \pm 17.62$ & 0.769 & NS \\
\hline Male Sex (\%) & $42.5 \%$ & $32.5 \%$ & 0.356 & NS \\
\hline WBCs (cell/cmm) & $1766.25 \pm 1918.36$ & $215 \pm 181.20$ & 0 & HS \\
\hline Polymorph \% & $86.83 \pm 10.73$ & $22.68 \pm 20.64$ & 0 & HS \\
\hline Lymphocytes \% & $13.18 \pm 10.73$ & $76.58 \pm 21.20$ & 0 & HS \\
\hline Protein & $312.48 \pm 174.38$ & $96.95 \pm 63.65$ & 0 & HS \\
\hline CSF/ serum glucose & $0.163 \pm 0.171$ & $0.539 \pm 0.166$ & 0 & HS \\
\hline CRP (N):0-6 mg/l & $24 \pm 9.11$ & $2.2 \pm 3.2$ & 0 & HS \\
\hline ESR & $44.53 \pm 34.28$ & $20.15 \pm 20.38$ & 0 & HS \\
\hline CSF IL8 (ng/ml) & $6.156 \pm 2.9539$ & $2.2595 \pm 1.73259$ & 0 & HS \\
\hline
\end{tabular}

Figure 1: ROC curve analysis showing diagnostic performance of CSF-IL8 for discriminating ABM from AM

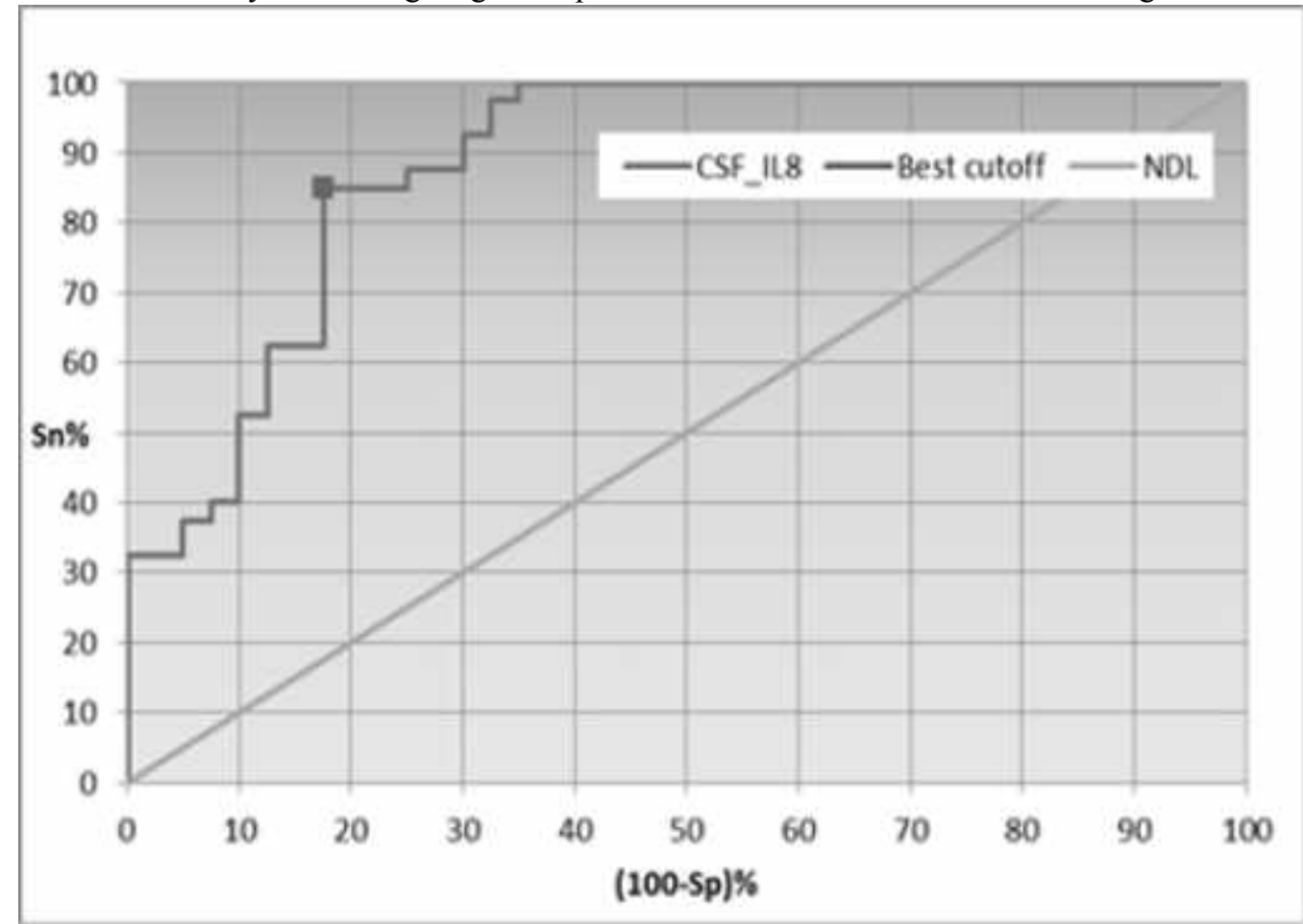


Table 2: Correlation between patients' characteristics and CSF IL8 among patients of both groups

\begin{tabular}{|l|l|l|l|l|l|l|}
\hline \multirow{2}{*}{ Variable } & \multicolumn{4}{l}{ CSF IL8 in ABM } & \multicolumn{2}{l|}{ CSF IL8 in AM } \\
\cline { 2 - 7 } & R value & P value & Sig & R value & p value & Sig. \\
\hline CBC TLC (cell/ml) & -0.01 & 0.949 & NS & 0.308 & 0.53 & NS \\
\hline CBC neutrophil \% & 0.303 & 0.057 & NS & 0.308 & .053 & NS \\
\hline CRP & -0.005 & 0.974 & NS & -0.119 & 0.465 & NS \\
\hline ESR & 0.459 & 0.003 & HS & 0.081 & 0.681 & NS \\
\hline CSF TLC & 0.364 & 0.015 & S & 0.039 & 0.813 & NS \\
\hline CSF glucose & 0.255 & 0.112 & NS & -0.341 & 0,021 & S \\
\hline CSF protein & -0.203 & 0.208 & NS & 0.019 & 0.91 & NS \\
\hline Serum/CSF glucose & -0.203 & 0.208 & NS & -0.14 & 0.311 & NS \\
\hline
\end{tabular}

\section{Discussion}

At the time being there was no clinical or laboratory method which can solely prove or disprove the diagnosis of acute bacterial or viral meningitis instantly and accurately. In this work we noted that the patients of the acute bacterial meningitis group had a higher value of CSF IL8 than those of the acute aseptic meningitis group with statistically significant difference between them. This result is in accordance with the similar studies (Ostergarrd et al, 1996; Yilmaz et al, 2012).

In the present study, the best cut-off value of CSF IL8 for early acute bacterial meningitis was $3.6 \mathrm{ng} / \mathrm{ml}$ with a sensitivity of $82.5 \%$, specificity of $85 \%$, negative predictive value of $84.6 \%$, a positive predictive value of $82.9 \%$ and a diagnostic efficacy of $83.9 \%$.Comparably, Ostergarrd et al. (1996) reported sensitivity value of $81 \%$, while, Printo-Geniour et al. (2011) reported high sensitivity $(100 \%)$ for CSF IL8 in differentiation between bacterial and aseptic meningitis. It is important to note that cut-off values for IL-8 may vary depending on variations of the methodology or reagents used, and before standardized tests are available one must determine the specific cut-off value under the conditions employed to ensure the best accuracy (PrintoGeniour et al, 2011).

Also, this may be due to false low levels obtained due to estimation of IL8 in early course of bacterial infection or using variable cut off points of CSF IL8 (Somasundaram et al, 2013).
In this study, the patients with acute bacterial meningitis had higher values of $\mathrm{C}$ reactive protein and serum leukocytes and polymorphs than those with aseptic ones with significant difference between them. but no significant difference in haemoglobin concentration, This result agreed with those of El-Kapany (2011) and Ibrahim et al. (2011), Arun and Sunit (2006) who stated that there was no significant difference in haemoglobin concentration and Viallon et al. (2011) and Alkholi et al. (2011) who revealed a highly statistical significant difference in CRP between patients with bacterial meningitis and those with aseptic meningitis This may be explained as serum $C$ reactive protein and ESR are reactive proteins activated by acute inflammatory process or acute bacterial infection. Makoo et al. (2010) reported that there was no significant difference in CRP between patients with bacterial and aseptic meningitis.

This might be explained as the initial CRP level can occasionally be low in bacterial disease, especially in the early stages. CRP concentrations begin to rise between 6 and $12 \mathrm{hr}$. and reach a peak level only at 24 to $48 \mathrm{hr}$. (Mary et al, 2003).

In the present study, in septic cases there was significant correlation between CSF IL8 and leukocytes, and a highly significant correlation between CSF IL8 and ESR). While, there was no correlation between CSF IL8 and other parameters as C reactive protein, CSF glucose, CSF protein, $\mathrm{CSF} /$ serum glucose ratio, age, duration and GCS. Regarding aseptic cases, 
there was a significant correlation between CSF IL8 and CSF glucose $(\mathrm{P}<0.05)$, without correlation between CSF IL8 and other parameters.

These results agreed with Ostergarrd et al. (1996), but disagreed with Ostergarrd et al. (1996) reported correlation between CSF IL8 level and each of CSF protein and $\mathrm{CSF} /$ serum glucose ratio.

The differential diagnosis between aseptic and bacterial meningitis in some instances can be difficult. A trust worthy laboratory marker would facilitate the clinical decision of interrupting antimicrobial therapy and avoiding unnecessary hospitalization. CSF IL-8 concentrations above $3.6 \mathrm{ng} / \mathrm{mL}$ would indicate bacterial meningitis confirming other clinical and laboratory findings. More studies performed in suitable models of meningitis are needed in order to establish the routine use of inflammatory markers in the diagnosis of infectious diseases of the central nervous system.

\section{Conclusion}

The outcome results showed that the CSF concentration of IL- 8 increased in the presence of meningeal inflammation. Consequently, the CSF IL8 could be an important tool to differentiate the acute bacterial meningitis from the aseptic meningitis.

\section{References}

Abdel-Ghani, SM, Hassan, EM, Masoud, S, Guirgis, NI, 1989: Rapid diagnosis of bacterial meningitis by latex agglutination test. J. Egypt. Pub. Hlth. Assoc. 64:31-44.

Abo-Madyan, AA, Morsy, TA, Motawea, SM, Morsy, ATA, 2004: Clinical trial of Mirazid $^{\circledR}$ in treatment of human fascioliasis in Ezbet El-Bakly (Tamyia Center) Al-Fayoum Governorate. J. Egypt. Soc. Parasitol. 34, 3:807-18.

Alkholi, UM, Abd-Al-Monem, N, Abd-ElAzim, AA, Sultan, MH, 2011: Serum Procalcitonin in viral and bacterial meningitis. J. Glob Infect. Dis. 3, 1:14-8.

Arun, B, Sunit, CS, 2006: Serum cortisol levels in children with acute bacterial and aseptic meningitis. Pediatric critical care medicine: J.
Soc. Crit. Care Med. Wld. Federat. Pediatr. Intens. Crit. Care Soc. 7, 1:74-8.

Dubos, F, Korczowski, B, Aygun, DA, Martinot, A, Prat, C, et al, 2008: Serum procalcitonin level and other biological markers to distinguish between bacterial and aseptic meningitis in children: A European multicenter case cohort study. Arch Pediatr. Adolesc. Med. 162:1157-63.

El-Kapany, RA, 2011: Serum and CSF cortisol level in patients with meningitis. Egypt. J. Neurol. Psychiat. Neurosur. 48, 4:391-7.

Ginsberg, L, 2004: Difficult and recurrent meningitis. J. Neurol. Neurosurg. Psychiatry 75, 1: S16-21.

Ibrahim, KA, Abdel-Wahab, AA, Ibrahim, AS, 2011: Serum procalcitonin in patients with acute meningitis: a comparison with blood leukocyte count and C-reactive protein. JPMA, 61:346.

Katz, N, Chaves, A, Pellegrino, J, 1972: A simple device for quantitative stool thicksmear technique in schistosomiasis mansoni. Rev. Do Instit. Med. Trop. de São Paulo, 14: 397-400.

Koedel, U, Klein, M, Pfister, HW, 2010: New understandings on the pathophysiology of bacterial meningitis. Curr. Opin. Infect. Dis. 23, 3:217-23.

Makoo, ZB, Ahadi, N, Hasani, A, Makoo, RB, Mashrabi, O, 2010: Cerebrospinal fluid ferritin for differentiation of aseptic and bacterial meningitis in adults. Am. J. Infect. Dis. 6:98-102.

Mary, P, Veinberg, F, Couderc, R, 2003: Acute meningitis, acute phase proteins and procalcitonin. Ann. Biol. Clin. 61:127-37.

Masoud, AA, Abdelkader, NA, Bayiomy, EM, Elshenawy, D, Khattab, EA, 2013: IgGindex as early predictor for neurological morbidity in Egyptian patients with acute meningitis. J. Egypt. Soc. Parasitol. 43, 2:407-14.

Ostergaard, C, Benfield, TL, Sellebjerg, F, Kronborg, G, Lohse, N, et al, 1996: Interleukin-8 in cerebrospinal fluid from patients with septic and aseptic meningitis. Eur. J. Clin. Microbiol. Infect. Dis. 15, 2:166-9.

Pinto Junior, Vitor, Laerte Laerte, Rebelo, Maria Cristina, Gomes, Rachel Novaes, et al, 2011: IL-6 and IL-8 in cerebrospinal fluid from patients with aseptic meningitis and bacterial meningitis: their potential role as a mark- 
er for differential diagnosis. Brazilian J. Infect. Dis. 15, 2:156-8.

Ruskoni, F, Parizzi, F, Garlaschi, L, Assael, BM, Sironi, M, et al, 1991: Interleukin 6 activity in infants and children with bacterial meningitis: The collaborative study on meningitis. Pediatr Infect Dis J. 10(2):117-121

Somasundaram, R, Nuij, VJ, van der Woude, CJ, Kuipers, EJ, Peppelenbosch, MP, et al, 2013: Peripheral Neutrophil Functions and Cell Signalling in Crohn's Disease. PLoS One 8, 12:e84521.

Straus, SE, Thorpe, KE, Holroyd-Leduc, J, 2006: How do I perform a lumbar puncture and analyze the results to diagnose bacterial meningitis? JAMA. 296, 16:2012-22.

Thwaites, GE, Lan, NT, Dung NH, 2005: Effect of anti-tuberculosis drug resistance on response to treatment and outcome in adults with tuberculous meningitis. J. Infect. Dis. 192:79-88.

Thwaites, GE, Lan, NT, Dung, NH, Quy, HT, Oanh, DT, et al, 2005: Effect of antituberculosis drug resistance on response to treatment and outcome in adults with tuberculous meningitis. J. Infect. Dis. 192:79-88.

Tsangaropoulou-Stinga, H, KanakoudiTsakalidou, F, Hatzipantelis, E1, Taparkou, A, Tzimouli, V, et al, 2003: Persistence of high levels of IL-6 and IL-8 in the cerebrospi- nal fluid of children with bacterial meningitis and prolonged fever. Hippokratla 7, 4:177-81.

Tunkel, AR, Hartman, BJ, Kaplan, SL, Kaufman, BA, Roos, KL, et al, 2004: Practice guidelines for the management of bacterial meningitis. Clin. Infect. Dis. 39, 9:1267-84.

Van den Bos, F, Terken, M, Ypma, L, Kimpen, JLL, Nel, ED, et al, 2004: Tuberculous meningitis and military tuberculosis in young children. Trop. Med. Int. Hlth. 9: 30913.

Viallon, A, Desseigne, N, Marjollet, O, Birynczyk, A, Belin, M, et al, 2011: Meningitis in adult patients with a negative direct cerebrospinal fluid examination: value of cytochemical markers for differential diagnosis. Crit. Care, 15:R136-42.

Waage, A, Halstensen, A, Shalaby, R, Brandtzaeg, P, Kierulf, P, et al, 1989: Local production of TNF-a, IL-1 and IL-6 in meningococcal meningitis: Relation to the inflammatory response. J. Exp. Med. 170:1859-67.

Wolff, B, Burns, AR, Middleton, JR, 1998: Endothelial cell "memory" of inflammatory stimulation: human venular endothelial cells store interleukin 8 in Weibel-Palade bodies". J. Exp. Med. 188, 9:1757-62.

Yilmaz, E, Gürgöze, K, Ilhan, N, Doğan, Y, Aydinoğlu, H, 2002: .Interleukin-8 levels in children with bacterial, tuberculous and aseptic meningitis. Indian J. Pediatr. 69, 3:219-21. 